\title{
DIASPORA KNOWLEDGE NETWORKS FOR DEVELOPMENT
}

$$
\text { By }
$$

Anusha Sundaram, BA, Webster University, 2006

\author{
A Major Research Paper \\ presented to Ryerson University \\ in partial fulfillment of the requirements for the degree of \\ Master of Arts \\ in the Program of \\ Immigration and Settlement Studies
}

Toronto, Ontario, Canada, 2010

(C) Anusha Sundaram 2010 
I hereby declare that I am the sole author of this major research paper.

I authorize Ryerson University to lend this paper to other institutions or individuals for the purpose of scholarly research.

I further authorize Ryerson University to reproduce this paper by photocopying or by other means, in total or in part, at the request of other institutions or individuals for the purpose of scholarly research. 


\section{DIASPORA KNOWLEDGE NETWORKS}

(C) Anusha Sundaram 2010

Master of Arts

Immigration and Settlement Studies

Ryerson University

\section{ABSTRACT}

This paper will consider the concept of Diaspora Knowledge Networks, (DKNs) and examine the relationship between DKNs and homeland development. Using a framework of World Systems Theory, it will lay out how skilled labour migration leads to diaspora network formation and that tactical brain circulation on the part of DKNs can provide home countries with the agency in the World System through a form of transnationalism from below. Recognizing that DKNs are socially constructed, and as a result replete with gender and power imbalances, it is posited that DKNs feed into and reproduce the global division of labour and with it all the implications for migration that go with this new global order. Finally this paper lays out the gaps within the literature on DKNs, namely in the areas of gender, race and the role of state securitization, and calls for further research so that policies harnessing DKNs for development may be more effective.

Keywords: Skilled Migration, Diaspora Knowledge Networks, Development, Transnationalism 


\section{Acknowledgements}

I would like to thank Dr. Anver Saloojee for his insightful and valuable comments throughout this process. Dr. Saloojee has acted as a mentor during my time in the ISS program and has been a source of continued support and guidance. I am also grateful to Dr. Grace-Edward Galabuzi for acting as the second reader and providing constructive comments during the oral review. Finally, I would like to thank my family and friends for their unwavering support and patience during the course of this year. 


\section{TABLE OF CONTENTS}

INTRODUCTION

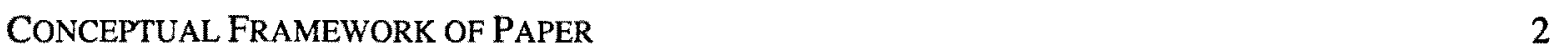

THESIS STATEMENT $\quad 3$

METHODOLOGY

THEORETICAL FRAMEWORK $\quad 4$

$\begin{array}{lr}\text { DEFINITIONS } & 9\end{array}$

LITERATURE REVIEW

SKILLED MIGRATION AND TRADITIONAL CONCEPTS OF BRAIN DRAIN 10

SKILLED LABOUR MIGRATION AND TRANSNATIONAL NETWORKS 14

$\begin{array}{lr}\text { NETWORK AND CONNECTIONIST THEORIES OF DIASPORA } & 18\end{array}$

DIASPORAS- CONCEPTS AND DEFINITIONS $\quad 21$

DIASPORA KNOWLEDGE NETWORKS $\quad 25$

DIASPORAS AND DEVELOPMENT $\quad 29$

SUCCESS STORIES: INDIA AND CHINA

GAPS IN THE LITERATURE $\quad 42$

CONCEPTUALIZATIONS OF DIASPORA

MIGRATION, DEVELOPMENT AND GENDER

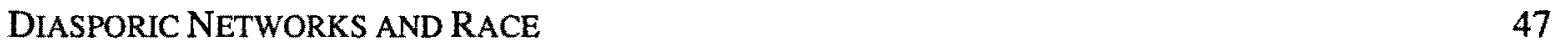

STATE SECURITIZATION AND DIASPORIC NETWORKS $\quad 48$

CONCLUSION $\quad 50$

REFERENCES $\quad 51$ 


\section{Introduction}

Migration impacts all areas of the world, particularly in the contemporary era of globalization. The movement of people across national borders for work was steadily on the rise in the late $20^{\text {th }}$ century as barriers to mobility were gradually eased or removed in order to meet a growing demand for certain skills and talents across countries ${ }^{1}$. This holds particularly true in the case of highly skilled labour mobility and the implications of these movements have come to be widely debated in the international arena. More recently, the term "diaspora knowledge networks" has begun to be used among social scientists to refer to the large numbers of skilled personnel who migrate every year from their home countries to join fellow nationals residing in countries other than their own. These diaspora knowledge networks are increasingly being considered a mechanism to promote development in their countries of origin through both direct and indirect investments. As a result, sending countries have formulated policies that help maintain bilateral relations between their diaspora communities and the country of origin. Two policies exist to enable states to derive the maximum benefits from the loss of human capital - the return and diaspora options. The former aims at the return of human capital and the latter at the diasporas' potential contribution through remittances, knowledge and technology flows that don't impact their physical locations. The debate about the benefits of harnessing diaspora networks for development in source countries reveals that the diasporadevelopment nexus is a complex subject, and one that needs to consider all the social,

\footnotetext{
${ }^{1}$ It must be noted that although the movement of people was on the rise in the late $20^{\text {th }}$ Century, the events of September $11^{\text {th }}, 2001$ changed the United States' immigration policy significantly and had far-reaching consequences for the framing of debates on the securitization of migration, both domestically and internationally. It is a fairly widespread perception that the threat of terrorism provided a pretext for the more rigorous exclusion of immigrants through instruments of migration control such as policies to exclude irregular migrants or other unwanted foreign nationals through entry restrictions, border control, apprehension, detention and deportation (Boswell, 2006).
} 
economic, political implications and the power imbalances for those involved. This paper will discuss both the theoretical and practical issues brought up by the diaspora for development concept.

\section{The Conceptual Map of the Paper}

In order to elucidate the concept of diaspora knowledge networks and their roles in homeland development, this paper will be broken down into four main sections:

Section 1 will look at the global migration of skilled workers and traditional concepts and theories of the "brain drain". This will lead into a brief discussion of transnationalism and transnational networks of migrants, and lay out the options for transnational populations to turn the "brain drain" into a "brain gain".

Section 2 will expand on the idea of transnational populations through an exploration of the concept of diasporas. Using network theories, it will analyze the roles of diaspora in brain circulation through the advent of Diaspora Knowledge Networks.

Section 3 will examine the notion of diasporas as agents of development through the lens of World Systems Theory and will consider the associations between diasporas, and development and the theoretical gaps within this relationship. The cases of India and China will also be used to expound on "diaspora success stories" where governments have successfully harnessed the power of their diaspora.

Finally, Section 4 will discuss the gaps that have been identified within the literature and make recommendations for future areas of research. 


\section{Thesis statement}

On the surface Diaspora Knowledge Networks (DKNs) seem to have a positive impact on developing the economic, social and political capital in both source and host countries, however increasingly research is showing that DKNs are suffused with the same tensions and social cleavages as society at large- cleavages such as age, gender, class and unequal power relations. While governments and policy makers in both the global North and South have largely ignored these issues for different reasons - in the North to fill skilled labour shortages and in the South to encourage remittances - these internal cleavages are simply manifestations of external cleavages present in society and policy makers must take them into consideration when looking to the future role of diasporas in development.

\section{Methodology}

This paper will be qualitative in nature and will undertake a critical discourse analysis of the existing literature on skilled migration, diasporas, diaspora knowledge networks and migration and development. Critical discourse analysis (CDA) is a theorizing framework situated within the social constructionist worldview and addresses the processes of interactions between actors while taking into consideration the historical, social and cultural backdrops that form them (Cresswell 2009). CDA primarily studies the relationship between discourse and power, abuse, dominance and inequality and how they are enacted, reproduced and resisted through text and talk in a social and political context. It also recognizes that the scholar's own background and experiences shape their interpretations of the subject matter and as such, there are limitations within my research. Firstly, my own epistemology and world reference can never be totally muted, no matter 
how objective I may have tried to be in my analysis of the subject matter and secondly, my analysis and interpretation is informed by other academic research which is also presumably influenced in some way

\section{Search strategy}

Research for the paper involved an in-depth literature search for diaspora knowledge networks and the roles of diaspora in development. The search targeted both private sector and public sector diaspora programs and organizations. A variety of key words were used to identify diaspora knowledge organizations, as there is no specific term that encapsulates the concept wholly. Searches were conducted by geographic region. Peerreviewed literature was searched using Medline, gray literature databases, and the Web sites of various diaspora knowledge networks as well as previous case studies on specific organizations. As a large amount of work that has taken place on diaspora is in the policy arena, working papers and publications from policy centers, think tanks, United Nations organizations and Non-Governmental Organizations were also considered. Searches were conducted in English and French.

\section{Theoretical Framework}

According to Wallerstein (1979) a world system is a "social system, one that has boundaries, structures, member groups, rules of legitimation and coherence [whose] life is made up of the conflicting forces which hold it together by tension and tear it apart as each group seeks eternally to remold its advantage". World Systems Theory contends that there is a hierarchy within nations and that they exist as core, semi-periphery and periphery countries. Within this, predominantly white, rich and militarily powerful Western nations are considered at the core, newly industrialized Asian and Latin 
American countries, as well as non-core Western nations make up the semi periphery, and most of Africa, as well as the poorest Latin, South and South East Asian countries make up the periphery (Patterson 2006). These nations possess changing levels of upward and downward mobility within the world economy and are able to move up from the periphery to the semi-periphery by seizing opportunities, accepting invitations from core nations or creating self reliance (Wallerstein 1979). Thus, the status of peripheral or semiperipheral nations is not rigidly set, and all nations have varying degrees of influence for upward mobility.

The last few decades have seen some very important changes and restructuring in the world economic system following the capitalism crisis in the aftermath of World War II. This restructuring led to the integration of the world economy in which countries were encouraged to "open up" their economies in order to expose them to competition from other countries (Brown 2002). The center/periphery relationship, so well articulated by Andre Gunter Frank (1984), has a great deal to contribute to our understanding of the development of underdevelopment, and of how the global system of capitalism has created a global division of labour that has hugely differential impacts on countries and on regions of countries. With the development of the capitalist system some regions have now become cores within the peripheries, such as China within Asia. In addition, one finds core centers within nations themselves, for example in India, with the Information Technology (IT) boom there has been an increase in migration from urban centers to developed countries in the North. Within India, there has been an increase in migration from rural areas to urban IT centers to fill the gaps in labour. Hence, migration is not 
only from the poorest to the richest; it is also peripheries to centers both within and across nation states (Portes and Walton 1981, p.31). Under this new globalized system, a country's competitive advantage is very much dependant on the level of skills of its workforce, and its ability to produce and disseminate knowledge for innovation. This fact is confirmed by the World Bank's World Development Report (1999) which posits that sustained economic growth and improvements in human well being is determined by knowledge, and not capital. This entrenches the stratification of the world system, and places industrialized countries at the core as they have the necessary resources to invest in research and development for innovation. It is in this context that the migration of the highly skilled is critical for any country, but more so for developing countries that are trying to improve their position in the world system and move from peripheral to semiperipheral and core positions. Transnationalism is one strategic means of advancing a nation's status from the periphery, and transnational diasporas networks play an important role in this. These networks have the capability to positively contribute to their homelands development through a form of "transnationalism from below". Transnationalism from below reveals a global networking of labour that goes beyond the simplistic notions of global movements of people across borders and reveals growing connections between local and global arenas due to flows of production, remittances and information. Diaspora Knowledge Networks are an effective system to facilitate the transfer and exchange of information between network members and between them and their counterparts in the country of origin. In this case, the development of new information and communication technologies plays an important role in facilitating the transfer of knowledge and information between actors in different parts of the world thus 
increasing their power and giving them greater agency within the world system. Bhabha (1999) characterizes the practices and identities of transnational migrants as counternarratives of the nation which evoke and erase boundaries and can be used as a counterhegemonic political space. Thus, far from withering away in the era of transnationalism, sending states once presumed to be "peripheral," are promoting the reproduction of transnational subjects; and, in the process reinventing their own role in the "new world order"(Castells 2010)

This process of globalization has also seen an increase in the movement of human labour capital, and a change in the global economy from more labour-intensive economies to more knowledge and technology-intensive industries. This change has brought about a segmentation in the global labour market turning it into a primary labour market characterized by highly skilled, well-paid jobs with good working conditions and a secondary labour market characterized by poorly paid, low skilled jobs with insecure working conditions and migrant networks. The UN Human Development Report states "the global labour market is increasingly integrated for the highly skilled [...] with high mobility and wages" (UN, 1999). Capital and production networks are globalised, while labour is local with only the elite specialty labour force being globalised. As such, it is the contention of this paper that DKNs, precisely because they are gendered and are a middle class phenomenon, feed into and reproduce the global division of labour and with it all the implications for migration that go with this new global order. 
Though Wallerstein offers us a good framework for understanding the role of Diaspora Knowledge Networks as agents for facilitating movement from the periphery to the core within world systems, this framework is no longer sufficient when considering the political and economic climate of the world today. Globalization has resulted in a restructuring of the world order, which has rendered obsolete the simple imagery of the center/periphery dichotomy (paralleling the North/South dichotomy), and the notion of developed and developing countries. The world structure now includes "vertically integrated regional division of labour based on geographic comparative advantage and horizontally diversified networks with actors [extended across borders] as part of corporate strategies of diversification and globalization" (Mittleman 1995). In other words, the old categories of world systems fail to fully understand the integration of the world economy and how transnational capital cuts across more traditional labour divisions and reorganizes the economy. For example, the emergence of BRIC countries like India and China ${ }^{2}$ that are increasingly important actors in the global economy have resulted in core and periphery centers within regions of the world. In addition, increased internal migration has also created core and peripheral areas within national boundaries.

\footnotetext{
2 It must be noted that while India and China are frequently cited as examples of diaspora success stories, not all developing economies are in a position to reap the benefits of brain circulation and peripheral entrepreneurship. This opportunity benefits countries that have invested heavily in higher education, typically technical education, and are politically and economically stable enough that immigrants will consider returning home.
} 


\section{Definitions}

The following are some definitions of common concepts and themes that will be introduced in this paper:

Brain Drain is the large-scale emigration of individuals with technical skills or knowledge as a result of lack of opportunity, political instability, or health risks. Brain drain is usually regarded as an economic cost, since emigrants usually take with them the fraction of value of their training sponsored by the government.

Diaspora Knowledge Networks are a system of coordinated research, study, results dissemination and publication, intellectual exchange, and financing across national boundaries" (Mahroum and Gouchteneire 2006)

Migrant networks are defined in the literature as recurrent sets of interpersonal ties that bind migrants and non-migrants together within a web of reciprocal obligations that can be drawn upon to facilitate entry, adjustment, and employment at points of destination (Portes, 1995) 


\section{Skilled Migration and Traditional Concepts of "Brain Drain"}

Global labour migration today can be divided into two streams, high-skill streams and low-skill streams. Workers who have both education and training characterize high-skill migration, while low-skill migration is comprised of workers who have limited or no higher education. Both official and public reactions to these two migratory streams reflect these differences. While high-skilled migrants are welcomed in most countries and are perceived to provide tangible human capital benefits, those emigrating with low-skills are considered to be a drain on the social system and a threat to host country solidarity (Kuznetsov and Sabel 2006). Though measuring the immigration/emigration of highly qualified people has always been a difficulty, due to the paucity of data that are accurate, reliable and comparable, the basic trends appear clear: the volume of skilled migration and its proportion as part of global population movement is increasing. At the same time however, developed countries have attempted to limit or control more effectively the entry of the less skilled, specifically in the permanency of their stays. For example, in Canada the number of temporary workers admitted on short-term visas has increased as a way of addressing labour demands in critical sectors, while overcoming the limitations of an immigration system that favors the highly skilled but creates shortages of "lowskilled" workers. This has created a dual approach immigration policy that is increasingly promoting skilled migration and limiting unskilled migration (Skeldon 2009).

Highly skilled workers have moved from industrial to developing countries for decades but there was a significant surge in numbers in the 1990s. The reasons for this increase are attributed to the IT-related economic boom, the influx of doctors and nurses from 
developing countries emigrating to care for the elderly in industrial countries and new opportunities for "side-door entry"- when foreigners entered as students and stayed to work (Martin, 2003 p.4). In addition, the implementation of regular immigration programs by developing countries, such as the points based skill selection systems of Canada or Australia, the introduction of non-immigration programs specifically targeting the highly skilled such as the H1-B program of the United States, or the recently opened channels for skilled migrants in France, Germany and the United Kingdom have facilitated skilled emigration in recent years.

Since a key attribute of skilled workers is that they have education and training that takes time to acquire, their numbers cannot generally be increased quickly unless trained workers who are not employed are induced to rejoin the work force or skilled workers are imported from abroad. As such, developed countries are increasingly trying to attract skilled migrants, but they rarely give any consideration to the impact that this migration might have on the migrants' countries of origin. The debate surrounding skilled migration, therefore, is about the benefits and losses of skilled migration, which are seen as a "brain drain" for source countries and a "brain gain" for receiving countries. The concept of the brain drain in the context of developing countries generally refers to the permanent or long-term international emigration of skilled people who have been received significant educational investments from their own societies (Wickramasekara 2003). 
The existing research and literature (Kuznetsov and Sabel 2006; Vinokur 2006; Martin 2003) point out that the transfer of skills and knowledge from countries of origin to host countries results in a serious loss in both human and economic power for source countries, as human resources are a key factor in the development and growth of these economies. In so doing there is a reproduction, through selectively induced migration, of the global division of labour and the reproduction of uneven centre/periphery relations. According to J-B Meyer (2001) the majority of scientific and technical results attributable to the citizens of developing countries are achieved and used in the North, even though their relative value would be much greater in the South. While, in terms of absolute numbers, middle-income developing countries such as India, the Philippines, Mexico and China have dominated the supply of highly skilled migrants, the relative impact of the loss of even small numbers of skilled workers is comparatively greater in smaller poorer countries (Skeldon 2009). For the purposes of this paper, the brain drain will be contextualized as the outflow of skilled labour from developing countries to developed ones, however it must be noted that the brain drain is not confined only to developing countries, it occurs at different levels within the developed world as well. There has been much work done on the loss of skilled workers emigrating from the United Kingdom, the loss of workers from Canada to the United States (US), and New Zealand's brain drain to Australia ${ }^{3}$.

\footnotetext{
${ }^{3}$ Though we discuss the movement of highly skilled migrants from developing to developed countries, it is important to recognize that the highly skilled do not always stay that way once in the host countries. High levels of training and education do not always translate into positivity and the deskilling of labour is a very common phenomenon.
} 
As with any debate, there are two sides to the brain drain argument. In what might be termed the "revisionist approach", it has been argued that the exodus of the highly skilled from the developing world can actually be beneficial and can lead to a "brain gain" for countries of origin. Although this viewpoint may initially seem counterintuitive this argument is based on the idea that skilled migrants leaving a country will generate an increased demand for higher levels of education among the population at large so that many more, might have a chance of emigrating. However, not all would obviously be able to do so and, at the most basic level of generalization, more highly educated people would be left in the source country (Martin 2003). According to the world-systems theory that defines migration as a subsystem of the world-system, the relation between globalization and migration follows the following process: First, globalization accelerates the process of industrialization and increases sectoral unemployment. These unemployed people become potential migrants that will immigrate to both more industrialized regions within the country or abroad. The more people migrate or want to migrate, the cheaper labour becomes in receiving countries and within big cities in sending ones (Sassen, 1988, p.53). For example, the Philippines are considered to have a "culture of migration", and individuals enter specific paths of training such as nursing with the specific goal of emigrating (Asis 2006). However, Kapur and McHale (2005, p. 95) criticize the generalizations made by the revisionist approach and cite India as an example. In India, it is estimated that one fifth of engineering graduates leave the country and they argue that it may be stretching a point to argue that the majority of these engineering students pursue this field of study with the thought of emigration. One must also consider the fact that were the revisionist approach 
were to hold true, the highly competitive screening policies of developed countries when searching for skilled workers would mean that even if there was a larger pool of skilled labour left in the source countries, this pool would be comprised of the less experienced lower quality workers that were discarded by developing countries. It can be argued that the empirical evidence to support the revisionist approach is weak or flawed (Skeldon 2009) - but it should be noted that there is also little evidence that offers clear support for the negative impacts of skilled emigration.

\section{Skilled Labour Migration and Transnational Networks}

The early 1990 s saw a rise in the theorizing of migration using a transnational perspective with work by cultural anthropologists such as Nina Glick Schiller, Linda Busch and Christina Szanton Blanco. They posited the view that contemporary migrants may not have completely left behind their old countries but were maintaining multiple connections and networks with them. This challenged the more traditional understanding of immigration prior to this period, which assumed that immigrants left behind their countries of origin and all ties upon entering a new country. Transnational practices became an enduring aspect of the lives of immigrants and long-term settlements of ethnic communities thanks in part to modern communication and transportation technologies.

This transnational perspective on migration gave rise to the notion of "transnational communities" and "diasporas" which leads to the conceptual problem of how to distinguish between the two concepts. While there is a considerable overlap between the two, and they are commonly used as adjectives, the term "diaspora" has been both more 
contested and more widely employed. Certainly, the concept of diaspora is so popular in academic circles that it has become a "mantra". Anthias, (1998) and Akenson (1995) posits that the "concept of diaspora is akin to a massive linguistic weed that threatens to take over the discourse on migration and settlement (Wong and Satzewich 2007, p.2). This paper contends that the term "diaspora" is itself not homogenous - there are class, race, gender and unequal power relations embedded within the "diaspora" that need to be considered.

An increasingly globalised world also leads to a change in the conceptualization of skilled migration. Researchers have put forward the idea that the term 'migration' particularly in reference to the highly skilled - may not be the most accurate term and that instead, 'movement' or 'mobility' may be more apt (Vertovec 2002). This is due to the fact that the term migration implies the notion of permanency or long-term stay, whereas an increase in globalization had transformed the movement of many highly skilled persons into intermittent moves and short-term stays (Koser and Salt 1997). With this increasing recognition of globalization and its impacts on labour movements, many social scientists and national policymakers shifted away from the discourse of 'brain drain'. New notions of the globalization of human capital, brain exchange, brain circulation and the creation of a global mobile workforce through skilled worker networks have emerged, with the idea of accepting the fact that skilled persons may want to emigrate for personal, familial and career development, while seeking to encourage the skilled migrant's return, mobilization or association with home country development. 
In a similar vein, Kapur and McHale (2005) posit that there are four key options or channels through which international skilled migration may affect sending countries these are prospect, absence, return and diaspora. The prospect channel discusses the way in which the prospect or option of emigration affects the population of the sending country. The prospect channel is the same as the revisionist approach to the brain drain, as discussed previously, where the mere prospect of emigration opportunities increases the incentive for the population to improve their educational status. The absence channel considers the effect on the population left behind when skilled migrants actually leave. At the most basic level this is a direct monetary measurement of the economic loss of the emigrants absence. More importantly, it may affect a county's capacity to build domestic institutions - the latter widely considered (Kapur and McHale 2005) to be the critical variable for development. The return channel looks at how emigrants who are returning to their home countries with financial, social and human capital can affect the domestic economy in ways that are different than if they had never left. With greater education, wealth, connections and contacts, and new ideas their impacts may be different if not greater on their domestic economies when they return. The final channel is the role of diasporas; those migrants who do not have to return but can contribute using transnational ties. There are two types of remittances that members of the diaspora may contribute towards their homelands - economic remittances and social remittances. Economic remittances are considered as significant resources for leveraging development and there has been a great deal of research, discussion and analyses around the effectiveness of financial exchanges (World Bank 2006). 
Advocates for migration as a positive force in development point to a large increase in remittance transfers to developing countries in recent years, remittances worth over $\$ 240$ billion per year (World Bank 2007). These remittances form the backbone of many developing economies, and though the common misconception is that financial remittance flows are primarily from the North to the South, the World Bank has recently estimated that between $35 \%$ and $40 \%$ of remittances received in the developing world come through South-South remittance flows (Sander 2003; Crush and Frayne 2007). Though financial remittances have been given a lot more 'airtime' in the public arena one would be remiss to think that financial contributions are all that diasporas have to offer. While monetary remittances may be important for augmenting and smoothening consumption, it is the flow of ideas, knowledge, technologies and business networks that are crucial for long term economic and institutional change.

For the purposes of this paper, the focus will be on social remittances, that is "the exchange of knowledge and skills that features the movement of social capital from overseas workers back to origin regions $[\ldots]$ where migration is transformed from a mechanism of brain drain to brain gain" (Bailey 2009, pp 376). There is a greater awareness by sending nations that although many migrants are unlikely to return, they can still advance state consolidation and national development from abroad (Levitt 2001) through social fields that link their homelands with their new diasporic locations. The motivation behind the creation and development of diaspora networks, and the commitment of its members can be explained by the mutually reinforcing process 
between human capital and social capital (Halliwell and Putnam 1999) and the propensity for highly skilled diasporas to get together and create associations fits within this pattern.

\section{Network and Connectionist Theories of Diaspora}

Network and connectionist approaches have been widely used across varied disciplines over the past few decades, and considering fields as varied as organization, information, migration and innovation through a network approach has allowed for many conceptual and empirical developments. In the field of migration in particular, references to "migrant network" can be traced to Choldin (1973) and with increasing precision, evidence and conceptual refinement, these migrant networks have been shown to facilitate the migration process. An understanding of the multiple roles of transnational networks - what Meyer (2001) calls 'a connectivist understanding' - provides an invaluable insight into the functions of, and policy issues around the mobility of highly skilled workers. Social ties in pre-migration networks are related to factors affecting which people migrate, the means of migration, the destination and future prospects for physical and occupational mobility. In addition, with the recognition of networks of skilled worker circulation, many social scientists and national policymakers have tended to shift from a discourse of 'brain drain' to notions of the globalization of human capital, brain exchange, brain circulation and the creation of a global mobile workforce. The idea is to accept human agency - the fact that skilled persons may want to migrate for personal, familial and career development, while seeking to encourage the skilled migrant's return, mobilization or association with home country development. Indeed, it is transnational networks of professionals that are deemed crucial to realize such goals, 
through transnationalism from below as mentioned previously.

The network approach has added considerably to the understanding of the migration process. Beyond the macro-economic factors such as the separate push and pull factors in different countries or the supply and demand of manpower, it points to micro- and mesolevel dynamics as major factors of what is actually happening. Network theories have been presented as both facilitating and channeling the migration process. Network connections with previous migrants provide many resources to potential new migrants, such as information about procedures, financial support, job prospects etc. These connections may be able to diminish the risks and costs of migration. In terms of channeling, social networks on migration flows may serve as natural pathways both geographically and occupationally. This type of channeling may also have limiting and exclusionary effects on individuals outside of the network who may not have adequate social capital to take advantage of the channeling networks. The networks utilized by migrants vary considerably depending on local histories of migration, national conditions and communal socio-cultural traits. As such, there has been shown to be variations in the types of networks used by skilled and unskilled migrants (Shah and Menon 1999). Skilled migrants, for example, rely more on networks of colleagues or organizations, whereas unskilled migrants rely more on kin-based networks.

Skilled expatriate networks specifically have the potential to turn the brain drain into a brain gain, by linking members of the diaspora with their countries of origin in a connectionist approach. The networks of these expatriates are diverse in nature: scientific, 
technical, institutional, professional, financial etc. and the goal for the country of origin is to tap into their expatriate professionals and the resources that are connected to them. Through the diaspora option, the country of origin is able to access the social capital that has been accumulated by their expatriates. The social capital being referred to here is much more extensive than simply interpersonal relations, it includes human capital, intellectual capital, symbolic and cultural capital, and institutional capital (Meyer 2007). Diaspora knowledge networks exhibit all three of the properties that are considered at the heart of social capital (Putnam 2000)- bonding, bridging and linking. Bonding is made up of the internal relationships within the diaspora network that help to build up a community. Bridging refers to the associations with distant and asymmetrical partners of different countries and linking takes place among the many members that are connected through the network.

It must be noted however that one cannot discuss migrant networks without also taking into account gender relations. It is important to highlight the fact that migration networks - both among skilled and unskilled workers - are class based (i.e. a middle class phenomenon) and significantly gendered. Gender and gender relations have a lot to do with shaping who one's contacts are, what one's relationship to them is, and how networks are accessed, managed and taken advantage of. This needs highlighting particularly in current discussions of skilled labour networks, since most recent literature on the topic has been marked by the 'invisibility' of women and gender relations (Kofman 2000). This gap will be discussed in further detail later in this paper 


\section{Diasporas- Concepts and Definitions}

The term "diaspora" is a highly contested term, the meanings and multiple referents that are being constantly theorized and debated by scholars within the field of diasporic studies. Concepts of diaspora have increasingly been used by anthropologists, literary theorists and cultural critics, and as a result have attained new epistemological, political and identitarian resonances. "Diaspora" literally means "scattering" or "dispersion" and was originally used to refer to the dispersion of the Jews to the lands outside of Palestine after Babylonian captivity. (Bhatt and Sahoo, 2003). Since the late twentieth century, the concept of diaspora has been used to describe ethnic populations that reside in countries other than their own homelands. While there has been much research undertaken on the development and operation of transnational business entities, only recently has the concept of transnational communities begun to draw the attention of social scientists. The terms 'transnational communities' and 'diasporas' are now increasingly being used interchangeably, and have come to be defined as:

"Populations of migrant origin who are scattered among two or more destinations, between which there develop multifarious links involving flows and exchanges of people and resources: between the homeland and destination countries and among destination countries." (Wickramasekara 2009)

Portes (1995), states that many immigrants today forge and sustain multi-level social relations that link them across borders. According to Portes, the multiplicity of involvements that migrants sustain in both home and host societies is an essential element of "transnationalism", and such involvements help to transform the home and host locations into transnational and global spaces. Different researchers have considered 
diasporas in multiple ways. Cohen (1997) for example categorizes diasporas under five categories and identifies specific transnational communities that fit into these typologies. According to Cohen, there are victim diasporas (Jewish, Palestinian, Armenian) labour (Indian) ${ }^{\circ}$ and imperial (British) diasporas, trade diasporas, (Chinese and Lebanese) cultural diasporas (Caribbean) and global de-territorialized diasporas. Vertovec (1997), unlike Cohen, has three typologies for the modern diaspora. Diasporas as a social construction is the most common in the literature, and is based on a diaspora's continued ties, both imaginary and actual, with a homeland despite its geographical separation. Vertovec's second typology is the diaspora as a type of consciousness that describes a variety of experience, a state of mind or sense of identity, which can be constructed negatively through mutual experiences of discrimination and exclusion, or positively by identification with a shared historical heritage. Thirdly, Vertovec considers diasporas as a mode of cultural production, contextualizing diasporic communities in globalism and transnationalism. Finally, other definitions of diaspora place emphasis on the traumatic nature of a community's exile from its homeland (Salehi 2007), the specific social relationships that have been constructed despite communities' dispersal, and the distinct identities that have been preserved by members of a specific diaspora that are distinct from those of the countries of settlement (Skeldon 2003).

Over the past decade, increased globalization has directed much attention to the mobility if the highly skilled, specifically the mobility of knowledge workers and new approaches have emerged in the study of diasporic communities as a result of rapid improvements in communication technology and international travel. Diasporas from this point of view are 
more often considered a phenomenon of globalization, and refer to "socio-economic and political networks of ethnic groups of people, which internationally connect diasporas to their homelands as well as to other members of the same ethnic groups living elsewhere" (Salehi 2007), where the development of new diasporic communities and networks can be attributed to changing migration flows within this globalised economy (Davies 2007). As was indicated earlier one of the interesting gaps in the literature is that "diasporas" are seen as homogenous entities when in reality they are socially stratified and gendered and contain unequal power relations within them. These networks allow for the possibility of participation in production/reproduction of a type of transnational culture (Appadurai 1990, 1996). But also further the reproduction of hierarchies of power and gender relations with the disapora itself.

It is increasingly recognized (Meyer and Brown 1999; Meyer 2001; Kapur 2001; Mahroum 2005; Kuznetsov and Sabel 2006) that diasporas may benefit the migration process both in sending and receiving countries. In immigrant sending countries, these networks strengthen ties with their emigrants abroad, in receiving countries they provide valuable international linkages that bring new ideas and skills. Ultimately, these networks also benefit the migrants themselves by giving them a platform for exchange of experiences and valuable contacts for their professional and private lives (Mahroum 2006). Diaspora networks which are social structures capable of identifying, capturing and mobilizing skills and knowledge produced in one context for application and use in another context are known as Diaspora Knowledge Networks, a concept that will be further explored later on in this paper. However it is also important to distinguish 
between the potential and actual contributions of the diaspora communities. While there is wide consensus about the potential of these networks, there is no guarantee that these potentials will be realized without some effort on the part of migrant communities or some intervention by destination and origin countries. In other words, the gap between 'promise and reality' needs special attention in diaspora discussions. Another point to highlight is that diaspora contributions can also be considered negative for home country's development where they prolong conflicts and fuel insurgencies. The cases of Eritrea, Kosovo, Somalia, Sri Lanka, Sudan, etc. are commonly cited as examples of diaspora engagement has created/continued negative situations (Vertovec 2004)

The contribution of diasporas to their home countries, be they positive or negative, can be broken down into the following three categories:

1) Economic: These include fiscal remittances, investments and exports. Migrants go abroad for higher wages, and remittances are the money that they send back to their home countries. Remittances to developing countries more than doubled in the $1990 \mathrm{~s}$ and the World Bank estimated that remittances being sent to developing countries by had reached $\$ 80$ billion by 2002 (Martin 2003). While financial remittances have the potential to positively contribute to economic development, some studies have suggested strongly that remittances create lasting negative effects on the country of origin. In the case of the Philippines for example, migration is said to have perpetuated a culture of dependence on remittances on the part of beneficiary families, as well as on the migrant sending country itself, and remittances have been used mostly for excessive consumption, not to increase the productive capacity of the 
sending country, contributing to local inflation (Asian Development Bank Report, 2004).

2) Influencing positive policy changes through lobbying, advocacy, mediation in their home nations

3) The transfer of skills, knowledge and technology

In recent years, there have emerged models that leverage the skills of diasporas in the third category. These include Technology and Research \& Development outsourcing networks, such as the Top Executives model in India where Indian executives in major multinationals influenced investment decisions to outsource knowledge-intensive operations to India. Other examples include knowledge outsourcing networks in Armenia where successful diaspora members send back outsourcing contracts to firms back home; venture capital networks in South Africa, Korea, China and Israel where managers and owners of start-up firms overseas help develop and finance commercially viable projects at home and brain circulation networks in China where incentives (like special technology parks) encourage the foreign living talent to come back home.

\section{Diaspora Knowledge Networks (DKNs)}

Towards the end of the $20^{\text {th }}$ century, groups of highly skilled expatriates originating from developing countries emerged and started to make connections amongst themselves and with their motherlands. The links formed by these transnational groups have received different albeit related labels: intellectual diaspora networks; scientific diasporas; technological and scientific diasporas; scientific, technological and economic diasporas; 
and finally, diaspora knowledge networks (DKN), a name given recently in a new project run by the International Committee for Social Science Information and Documentation at UNESCO.

Diaspora knowledge networks are described as "a system of coordinated research, study, results dissemination and publication, intellectual exchange, and financing across national boundaries". Actors in these networks may be comprised of professional bodies, academic research groups and scientific communities focusing on a specific issue with their primary motivation being to create and advance knowledge as well as to share, spread and, in some cases, use that knowledge to inform policy and apply to practice (Mahroum 2006)

A major area of attention in recent literature has been on the potential of this intellectual and scientific diaspora to transform brain drain into brain gain in the context of home countries. Diaspora Knowledge Networks provide a new option for homeland development in three key policy areas: innovation, migration and development and cooperation (Meyer, 2007). According the Global Commission on International Migration, diasporas should be encouraged to promote development by saving and investing in their countries of origin and participating in transnational knowledge networks. Diasporas could act as partners and stakeholders for their home countries and fostering contacts with these citizens abroad, especially with those who are highly skilled, may facilitate the emergence of more active knowledge networking and the diversity. Repeated waves of emigration have led to the creation of vibrant diasporas that possess 
cutting-edge technology, capital and professional contacts. As such, theoretically DKNs should provide contacts, transfer of skills, virtual linkages and represent in this sense a brain bank to be drawn upon by the home country. DKNs are also said to facilitate the other two brain gain mechanisms: strategies of investment in research and experimental development, and North-South research partnership programs. (Wickramasekara 2003).

As soon as they appeared, diaspora knowledge networks raised as many doubts and critiques as they did enthusiastic expectations. The skepticism and critiques that have surfaced essentially focus on two aspects: the consistency and the sustainability of these networks, and their real impact on developments in countries of origin. (Meyer 2001)

Diaspora initiatives are easy to start but it is difficult to maintain momentum unless concrete results materialize. There is a need for significant technical, human and financial resources to make them sustainable. Lack of strong leadership or individual champions and ineffective follow up mechanisms are other causes (Wickramasekara, 2007). Ultimately, DKN need counterpart infrastructure and institutions in their home countries. This is what Kuznetsov calls the Paradox of Diaspora Initiatives (Kuznetsov, 2004). In his view, it is a paradox that for effective utilization of diaspora potential one needs capable institutions at home

The other criticism relates to the effectiveness of these networks on the development of the source countries. Some analysts have found that the countries with more active diaspora knowledge networks are those in the "emerging economies" category. Many of 
these are located in Asia and have a better academic and industrial environment than most developing countries. The most common example given in the literature on DKNs is that of the expansion of the Indian computer industry. This expansion is often attributed to the crucial input provided by associations of Indians working in Silicon Valley, yet this factor appears to count for less than the presence of local labour that is cheap and highly skilled. This raises some basic questions about the direct or indirect link between diaspora initiatives and local development. While a direct link does seem hard to establish - as it is in general for any knowledge input (educational or R\&D) into the economy - there are some striking coincidences that bear it out. At the very least, diasporas help "to create positive externalities that can be used by their networks to boost markets, which become more buoyant" (Meyer $2005 \mathrm{p} \mathrm{12).} \mathrm{The} \mathrm{evidence} \mathrm{on} \mathrm{their} \mathrm{impacts}$ should not be solely considered through cause and effect but should be considered and analyzed in a larger socio-economic framework in order to gauge their impact on development.

Despite the criticisms that have been aimed at them, DKNs have deeply changed the way in which highly skilled mobility is looked at. They have conceptually changed the traditional "brain drain" migration outflow into a "brain gain" skills circulation by converting the loss of human resources into a remote yet accessible asset of expanded networks (Meyer et al. 2001). This has shifted the traditional emphasis, focused on the option of return migration and the embedded knowledge of potential returnees to a connectionist approach where social capital, including technical and institutional links, is crucial (Meyer 2001) 


\section{Diasporas and Development}

Development and migration had for a time been treated as separate policy fields and only recently has the concept of using transnational networks of migrants as a policy option for development been presented (Kuzetsov and Sabel 2006; Vertovec 2002, Meyer 2001; Meyer and Brown 2001; Skeldon 1997; Mohan 2000). The link between the spatial organization of populations and development has been an ongoing theme within the field of population geography (King 1986, Skeldon 1997, Bailey 2009) and the 'migration development nexus' in particular has become a central focus of the global development agenda over the past decade (Haque, 2004).

Traditional debates around the links between migration and development posit that the relationship is cyclical in nature - while underdevelopment is among the root causes of international migration, international migration can be detrimental to development through the loss of highly skilled nationals and the depletion of the national labour force. These debates on the "brain drain" can be distinguished by how the discourse changed in two phases over the past 40 years. The first phase took place in the 1960s and 1970s, when movements of highly skilled people in the global South were moving to the global North. Prior to this phase, there had been great enthusiasm and optimism revolving around the development of Africa, Asia, and Latin America during the postcolonial era in the 1950s where it was assumed that investment, education, and modern management would be sufficient for their economic growth. However, by the 1960 s the expected development process by remained uneven and international gaps between the developed and the less developed countries widened rather than narrowed. There was also a growing 
demand for migrants to work in the service sectors in the developed countries and with immigration laws relaxing in the developed world, this migration soon became a trend with both students and educated professionals leaving their home countries.

The brain drain has been associated with underdevelopment with those who believe educational levels determine why some countries are rich while others are poor. With the highly educated leaving their countries of origin it is generally assumed that the nation incurs substantial losses in the money it put into the training of the individual. Thus, the common assumption during the first phase of discussion around the brain drain was that the loss of the skilled would prejudice the countries of origin and academics and researchers put much emphasis on the consequences of these movements and what would constitute adequate means of compensation.

The second phase in the debate around the brain drain took place in the early 1990s, where the world was increasingly globalised, there emerged a global division of labour, and was experiencing a boom in information and communication technologies. Whereas the earlier concerns over the impacts of the brain drain were related to more permanent or settler migration, current discussions take place in the context of temporary, contract or circular migration. This means that the immigration process doesn't end in permanent settlement, integration and citizenship in the host country anymore, rather, the development of communication technology and facilitated travel means that migrants are able to "simultaneously integrate into the host country and maintain ties with their homeland. 
The relationship between migration and development are multiple, variable and countryspecific and do not conform to any "one size fits all" style explanation. While it is easy to vilify developed countries that seek to attract skilled foreign nationals and use the brain drain as an explanation for a lack of development in source countries, the inverse must also be considered - that the brain drain may actually be a result of increased development. Theories of development are also not possible without considering how nations' past economic and social histories have given rise to their present underdevelopment. This leads to assumptions that their past (and present) is similar to the development of now developed countries, and fails to explain "the structure and development of the capitalist system as a whole and to account for its simultaneous generation of under-development in some of its parts and economic development in others"(Gunder Frank 1984). Ultimately, for every global generalization on the impacts of migration on development, there will always be the exception to the rule. Benefits and losses from skilled migration are not one-way flows and scholars looking at the migration-development nexus must consider the multiple impacts of skilled emigration on source countries. These impacts may be both positive and negative and the following list will simplify and categorize these outcomes.

\section{Positive Impacts:}

- Provides opportunities to educated workers that are not available at home.

- Inflow of remittances and foreign currency to sending countries

- Return of skilled migrants increases local human capital, transfer of skills and links to foreign networks 
- Technology transfer, investments and venture capital by diasporas

- Circulation of brains promotes integration into global markets

- Information and communication technology allows countries to benefit from diasporas.

\section{Negative Impacts}

- Net decrease in human capital stock in source countries, especially those with valuable professional experience

- Reduced growth and productivity because of the lower numbers of human capital

- Monetary loss of heavy investments in subsidized education

- Remittances from skilled migration may taper off after some time.

- Students educated at government expense or own resources in foreign countries imply further drain

- Causes increasing disparities in incomes in country of origin.

(Wickramasekara 2002)

As migration has steadily climbed up the list of public and policy concerns, it has become increasingly recognized that migration can be affected, intentionally or not, by interventions in the areas of development policy and assistance, as well as by wider policies and practices in the foreign and domestic affairs. Assessments of the influence of migration on development have varied over time: sometimes migration has been seen as beneficial and at others detrimental to development, depending on the historical moment and circumstances. And with the variation in perspectives has come variation in migration and development policies. Recently, there has been far more policy research than academic research undertaken in the area of migration and development and as a result focuses on the needs of policy makers wanting to harness their development 
potential. As such, the research is preoccupied with the potential of economic and social remittances by individual migrants, while failing to address new issues in development that go beyond material and technical aspects, for example the importance of temporary migrants in the development discourse (Mercer 2008). As a response to this latest research on diaspora in homeland development, many sending states have provided migrants with special rights, protections, and recognitions, in the hope of ensuring their long-term support (Guarnizo 1997; Roberts et al. 1999; Nyberg-Sorensen 2002), in an interplay between "transnationalism from above" and "transnationalism from below". Transnationalism from above involves governments and international elites whose activities are mediated at the macro-level by Multi-national Corporations and other supranational entities; while transnationalism from below involves non elites/ ordinary people whose everyday macro- and micro-level activities generate multiple and counter hegemonic forces. Diaspora Knowledge Networks represent a form of transnationalism from below, as evidenced by their practices of numerous "home-state" and "home-town" associations that connect migrants and their economic and social resources to their homelands, and that often promote community development projects (Goldring 1998; M.P. Smith 2001). Transnationalism from above can be seen in governments that offer bonds at high state-guaranteed rates of interest in order to take on major national development projects by mobilizing worldwide diasporic loyalties such as in the case of India and China (Rayaprol 1997; Sengupta 1998). Diaspora networks enable a country to have access not only to their skilled citizens no matter where they reside but also to the socio- professional networks in which they have become inserted abroad. Their transnational networks can be useful in attempts to build a locally based enterprise by 
connecting them to a far-reaching 'research and technico- industrial web' and the resultant long-distance networks among local and foreign-based professionals can provide important channels throughout which run flows of capital, skill, managerial know-how and information. This type of strategic brain circulation specifically on the part of the Chinese, Indians and more recently Mexicans can be considered a form of politico-economic agency that has been powerful enough to overcome the predominance of the West (Patterson 2006), giving these nations agency and upwards mobility with the world system.

While the migration-development nexus has caught the attention of both scholars and policy makers there has been little distinction made between migrants and diasporas. Instead of re-conceptualizing what diasporas can bring to the development process, diasporas are just being incorporated into existing models of migration and development. Migrants and diasporas are not the same, and while migrants are often conceived in a pejorative light, diasporas avoid this conceptualization and open up the discussion around the notion of mobility. Migration as a concept also treats movements of people as a collective of rational acts of individuals based on incentives and opportunities, whereas diasporas are associated with the argument of both leaving and a longing for "home", insinuating emotion and desire (Mercer 2008). To elaborate, economies of diaspora are not necessarily capitalist economies and do not follow capitalist logic - they are tied to politics of obligation based on kin and community. Therefore diaspora engagement with development is more complex than usually acknowledged in discussions concerned with economic and political impacts of migrants distinguished by "collective" engagements 
with home. As a result, diasporas cannot simply be added to migration-development nexus frameworks, even though diasporas have made important contributions to development in material terms. There has been a lack of discussion around diasporic identities and their relationships to development. And the interests and capacity of diaspora organizations may be extremely varied: some are geographically powerful, others impact small geographic areas, while other still work on a sporadic basis and some are networks in name only (Newland and Patrick 2004).

Diaspora-homeland collaborative development is founded on sentimental and material arguments for a bounded ethnic group, both within the diaspora and between it and its homeland (Patterson 2006). However, diaspora studies have worked hard at creating an analytical framework that understands diasporas as a fluid entity, not rooted in place and asserts de-territorializated and placeless notion of diaspora. Though diasporas do break the link between identities and place because they are physically located in new spaces, they can constantly remake the home they came from. Place and identity are co-produced continuously through diaspora, an area under-looked in the literature on diaspora. In the same way that development challenges theories of diaspora, diasporas challenge core assumptions of space and agency rooted in development studies. This may be the reason why critical development studies has only recently begun to engage with debates on diaspora. Bringing diaspora and development together thus allows for the opportunity to link political economy with questions of culture and identity. 
One critical study that does take into account the intricate relationships in development being undertaken by diasporas is that by Giles Mohan (2000). According to Mohan, the relationships between diasporas and development can be classified in three simultaneously independent and interdependent ways: Development by the diaspora, development in the diaspora and development through the diaspora. Development by the diaspora refers to the diaspora working chiefly in helping the homeland develop. Development in the diaspora relates to the benefits accrued in host societies due to the presence of international migrants. This occurs through the pooling of financial, intellectual and political capital by members of a diaspora, in order to grow wealth and provide a measure of security and independence within their host country. Homeland nations may support initiatives for development in the diaspora for two reasons: in order to help their nationals succeed for their own good, and more importantly, in order to help their nationals become financially and politically strong enough to be able to significantly and effectively contribute to the development of their homelands. One such example is that of South Korea, where, in the 1960 s and 70 s, the State helped the diaspora flourish within the export industry in California. As a result the Korean diaspora has contributed to the development of South Korea through the transfer of their knowledge and skills, and studies show that wherever Koreans reside in the diaspora, trade between that country and South Korea is positively affected (Patterson 2006, p.1898). Development through the diaspora are additional benefits accrued through the transnational connections of migrants to the host country. It considers development as a result of ties within and between diasporas of the same ethnic group around the world. The best example of this 
type of development is the Chinese diaspora, and development through the Chinese diaspora will be discussed further below.

\section{Diaspora Networks for Development "Success Stories": India and China}

China and India are frequently cited as "diaspora-development success stories", and are considered nations that have successfully harnessed their diasporas in order to made astute use of knowledge and technological transfers (Davies 2007; Saxenian 2002; Kapur 2001). Many countries are now trying to engage in similar policy options but have been slow to realize the potential for development beyond financial remittances. This may be due to the common critique around the efficacy of DKNs on development - some analysts have found that countries with more active diaspora networks are in "emerging economies", many of which are located in Asia and whom are enjoying a better academic and industrial environment than most developing countries.

\section{India:}

The Indian Diaspora is an important force in the world economy. The majority of the Indian diaspora is a result of colonization by the British in the $19^{\text {th }}$ Century, where Indians were moved as indentured labourers to South Africa, East Africa and to British Colonies in the West Indies, as well as French and Dutch Colonies such as Guadeloupe and Suriname. Following World War II, Indians migrated to Europe to aid in reconstruction of the continent, and more recently Indian emigrants began moving to the UK, the US, Australia and Canada as a form of skills migration. Today, it is estimated 
that there are close to 20 million Indians living in over 110 countries worldwide, and in places such as Malaysia, South Africa, Australia, Uganda and the United Kingdom they constitute prominent minority communities. This diaspora is made up of "NRI's" or Indian Citizens that are not resident in India, and "PIO"s, Persons of Indian Origin that have the citizenship of another country.

The Indian Diaspora has been particularly successful, and have has a significant impact on both the economy of the host countries as well as that of their homeland, in both businesses and knowledge intensive fields such as information technology, Medicine, engineering and accounting (Pandey et al. 2004). In particular, Indians in the United States are amongst the most successful immigrant communities in US history, and have an average median income that is substantially higher that the US median income, a higher rate of tertiary education and an above average number of management or professional positions. Indians in the US have the been the highest recipients of $\mathrm{H}-1 \mathrm{~B}$ visas, a US visa program that allows foreigners to move to the US for employment in areas that are considered critical to the economy.

One of the most popular cases when discussing the positive contribution of the Indian diaspora is the role they have played in the Indian Information Technology industry's development. Although it is almost unanimously agreed upon by scholars that's the role of the diaspora has been important, to what extent they have played a role is still questioned. Some authors (Lucas 2004; Kapur and McHale 2005) posit that the diaspora input is just a matter of an availability of cheap and skilled labour, while others consider 
the direct contributions and interventions of expatriate Indians in the United States as crucial to the development of Information Technology cities like Bangalore.

India, like many other countries, considers its diaspora as a source of economic development and has taken a proactive, comprehensive and strategic approach to its diaspora-homeland collaboration development effort (Patterson 2006). One such approach was the establishment, in 2000, of a High Level Committee on Indian Diaspora by the Indian Government in order to analyze the location, situation and the potential development potential of the Indian Diaspora (Newland and Patrick 2004). The Government of India has also implemented policies in order to cultivate investment, trade, and technology/knowledge transfer through the Indian Diaspora. According to Newland and Patrick (2004), the Indian Government's policies are "multi-pronged, pursuing direct investment, portfolio investment, technology transfer, market opening and outsourcing activities" (pp v). The Government has a business-oriented attitude towards its diaspora, one that is focused on reaching out to the Diaspora as a means for national development as opposed to as a tool for poverty reduction. The Indian State has

"sought to induce non resident Indian to deposit their savings in Indian banks, invest in Indian companies and start their own businesses in India... the Indian Embassy ahs also encouraged the Indian community in the United States to actively support Indian foreign policy objectives in Washington" (Myron-Weiner 1990, p. 202) 
The High Level Committee on the Indian Diaspora released a report in 2001 that recommended new policies be implemented in order to create a "more conducive environment in India" in order to leverage the invaluable human resources of the Indian Diaspora (Singhvi 2001). As a result, policy reforms were implemented by the Indian Government that included dual citizenship for persons of Indian origin, simplification of investment in India from abroad, and the creation of a "Division of Non-Resident Indians and Persons of Indian Origin" within its Ministry of Foreign Affairs. These moves demonstrate how India is fully embracing the strategic diaspora-homeland development model.

\section{China}

The Chinese diaspora started within seafaring communities and trading outposts in coastal China, and later progressed to increased labour migration in the $19^{\text {th }}$ century where Chinese migrants from both the coast and inland worked within the European colonial sphere (Biao 2005). Political and economic tensions in the $20^{\text {th }}$ century dispersed the Chinese diaspora even further (referred to as a diaspora within the diaspora) while at the same time Western nations removed the racist economic and immigration policies that excluded Chinese. Throughout, thee government of the Peoples Republic of China tried to maintain a sense of Chinese identity among overseas communities and since China's economy opened up in 1979 the economic dimension has been dominant, with an increased effort to combine sentiment and incentives to attract investment from the diaspora. This has not just been applied through the central government, but also through local entrepreneurs that are emphasizing migrant ties to ancestral villages. 
China represents one of the best examples of how governments can carefully cultivate their populations abroad, turning brain drain into a brain gain. Popularly referred to as the "bamboo network", the overseas Chinese network comprises 55 million people and $\$ 700$ billion per year that provides floating capital for Chinese diaspora businesses around the world, investments in foreign enterprise and investments in China (McKinsey and Company 2003). Much like India, China has focused its interactions with its Diaspora much less on remittances and more on different business models that impact on development. China has long worked to attract direct investment and open trade opportunities through overseas Chinese communities, and the Government of the Peoples Republic of China has actively tried to maintain a sense of national identity amongst its Diaspora by creating incentives for the Diaspora to invest in their homeland (Newland and Patrick 2004).

\section{Significance}

India and China demonstrate how the old pattern of one-way flows of technology and capital from the core to the periphery is being replaced by a far more complex and decentralized two-way flow of skill, capital, and technology between differently specialized regional economies. Silicon Valley is now at the core of this rapidly diversifying network of economies because it is the largest and most sophisticated market as well as a leading source of new technologies. However, this too could change: the relationships between these emerging technology regions are multiplying and new markets are opening up in China and India that promise to further transform the dynamics of the world economy. 


\section{Gaps in the Literature}

\section{Conceptualization of the Diaspora}

As was indicated earlier one of the interesting gaps in the literature is that "diasporas" are seen as homogenous entities when in reality they are socially stratified and gendered and contain unequal power relations within them. Diasporas are created through structural and subjective conditions that are determined by historical forces and the structure of power relations in both sending and receiving countries. However there have been few attempts among scholars to develop a political economy of diasporas in an age of globalization that takes into account the importance of power relations and inequalities, political interests and agendas in order to substantially address the complexities of diaspora (Davies 2007; Vertovec and Cohen 1999; Koser 2003; Reis 2004). In addition, while the conceptualization of diasporas attempts to loosen conceptual boundaries of identity, it has actually reverted to a rigid and traditional understanding of culture, ethnicity and geography by referring to diasporas as a homogenous groups (Davies 2007). The literature also has been slow to address the position of agents within the framework of a globalised economy or discuss the depth and power of diasporic identifications, and the way in which class, gender and other social alignments may change diasporic relations and create new or changing diasporic identities. It is important therefore to reconceptualize diasporic identifications and connections as context specific processes of political economy. This will allow us to take into account how the processes of globalization have changed social relations (e.g. making short term migration more important) and made population flows more complex, highlighting the fact that diasporic communities are both complex and varied in structure and character. In this deconstruction and reconstruction/reconceptualisation of "the diaspora, issues of class, 
gender, race, ethnicity, religion and other social cleavages need to loom large, for diasporas are not homogenous.

\section{Migration, Development and Gender}

Current knowledge regarding international relations between international migration and development is incomplete and there has not been a consensus on either cause or effect. Given the multiple ways in which international migration interact with development and the tendency of research to focus on just a few of these interactions, the existing knowledge on the inter-relations between international migration and development is far from complete and generalizations are not possible. Theories are important for predicting and understanding mechanisms of development and migration but the concern should be around how to increase the efficacy of development programs in developing counties and encourage participation in economic growth through engagement in international trade.

As mentioned previously, gender as an element of migration has not entered the mainstream migration network debate in general, and in migration and development specifically though much work has been done on gender at different stages of the migration process. Though this paper will not be focusing on migration and gender in any detailed way, it is important to note that in the new millennium, new subtypes of migrants are emerging, including young single women or female family breadwinners who move independently rather than under the authority of older relatives and men. . While female migration may form part of an integrated family strategy, it may also take place within female networks, separate from those of men. Piper (2005) and Fry (2006) suggest that female migration is on the increase within as well as from several parts of the developing 
world. Female migrants from less developed countries differ in terms of background, and include women from both rural and urban backgrounds migrating alone or through family reunification programs and low skilled women from urban areas. Female migrants are increasingly migrating alone because of divorce and poverty, and women with secondary or higher education involved in autonomous migration because they were unable to gain jobs in line with their qualifications at home and finally women fleeing civil unrest. Gender relations are also deeply implicated in the formation of networks and the way in which they are managed, sustained and used to derive social and economic benefits. As such, gender is an important component in the discussion around Diaspora Knowledge Networks Diaspora Knowledge Networks are a gendered entity, socially constructed to construe professional middle class male networks with no purview on women's issues. However, as much of the work on Diaspora Knowledge Networks is in policy creation and implementation, gender and gender relations have not been taken into account within the discussion.

Recent policy and academic debates take for granted that migration can and will contribute to the development process through remittances brain circulation and transfer of practices and ideas but these discussions don't point out the diversity of actors involved or the differences in development visions and interests that are embedded in relationships of knowledge and power (Dannecker 2009). The literature discusses how transnational identities are changing and evolving due to transnational practices and international mobility so one would assume that it would be important to consider how visions of development and social change are linked to these new identities. As 
mentioned previously, diasporas are not a homogenous group or a singular actor, and differences in the development visions of highly skilled migrants, temporary labour migrants and refugees are not addressed, much like gender is neglected in the discourse. Even though gender is considered crucial to understanding transnationalism, many gender related topics remain under-researched and un-theorized (Pessar and Mahler 2003, p. 812) and migration and development policies often ignore migrant's gendered identities and practices.

The interests and activities of male and female migrant actors are varied and may therefore result in transformations and processes that were not the economic ones foreseen by International Organization, NGOs, and governments. In many cases, women's relationships to their cultures of origin are stronger than men's, especially when they have left behind children and parents during the migratory process. Female migrants not only tend to be better remitters, they also tend to organize around important development issues of family welfare, schooling and the local environment.

When women are targeted as a special group, their transnational engagement in both sending and receiving societies is often overlooked. It is therefore important that policies are designed according to the opportunities and constraints specific to different groups (for example women and men, younger and older women, autonomous or dependent female migrants), as well as according to specific groups' transnational spheres of action. Migrants not only contribute remittances while abroad. They also contribute new skills and life views whether they return or not. Their abilities to do so depend on whether they 
have equitable access to services and training. International agencies should therefore approach migrants' gender-specific concerns and make sure to follow up effectively on gender awareness campaigns and programs when women return. Unless properly assisted, women may lose newly gained gender rights to men, who seem to regain their traditional gender privileges upon return (Pessar 2001). In addition, development that is considered from a purely economic perspective cannot capture the complex and diverse processes of migration that has implications for agency - while male migrants have organizations and collective agencies formed, female migrants do not have the same influence. As suggested by Pessar and Mahler, transnational migrant development activities can be usefully analyzed within a framework of gendered geographies of power.

Sticking to structural, technocratic or uniform development concepts and approaches, means that neither agency, gender relations, nor social and cultural dimensions are taken into account. These concepts and approaches, which have been increasingly questioned and challenged as modernistic or Northern biased, do not reflect the new complexity of migration processes and actors. Visions of development as well as the agency of those involved are changing in a globalizing world, as are the features of migration processes. Brain gain strategies such as Diaspora networks are difficult to measure and define, but in theory are able to leverage a network, raise fund, get mentorship and access distribution channels, promote image of country and spawn more enterprise. However, without understanding the different visions and interests of the actors and without analyzing the respective social and cultural contexts in which these visions are embedded and localized, intervention strategies regarding migration or development policies will not work, as 
have previous development approaches and concepts. There is therefore a need for indepth studies on the changing notion of development and its negotiations, a case by case analysis is needed based on country and region specific macro economic conditions as general theories linking migration and development cannot be adopted across countries and regions. The production and negotiation of knowledge about development and visions of development and the role that migration and networking can play within these processes should increasingly be the focus. Only then can policies and strategies can be developed by national as well as international organizations and institutions that are embedded in the different understanding of development. These in turn will serve as a mirror of the changing economic and social capacities, priorities and choices (Nederveen Pieterse 2001) of a globalizing world (Dannecker 2009).

\section{Diasporic Networks and Race}

This paper has not attempted to address the racialization and diasporic networks but at a transnational level race and racialization is an important issue and one that is highly discussed topic in popular media today ${ }^{4}$. Unfortunately, the dominant knowledge structure in International Relations has deflected discussions on transnational issues of race and the fact that racialized ethnicity is an instrument in the regulation of society and international migration (Mittleman 2001). Transnational/trans-regional networks and diaspora consciousness may then be constituted as a result of shared histories of colonial and neocolonial exploitation and experiences economic and racial marginalization in host

\footnotetext{
${ }^{4}$ Examples such as the ethnic heritage of President Barack Obama, protests in the French suburbs by immigrants and subsequent generations and in matters of state security and "those who should be allowed in or out"
} 
countries $^{5}$. In terms of Diaspora Knowledge Networks, while not always racialized, they tend to be racially homogenous- as they are socially constructed and rely on social capital grow. In addition it seems that certain ethnicities are favored as positive diaspora network contributors over other, but, being a new phenomenon on the field of international relations, generalization cannot be made regarding the relationship between DKNs and race.

\section{State Securitization and Diasporic Networks}

Another gap in this paper, and in the existing literature in general is the security-diaspora nexus. Since September $11^{\text {th }}$, the discursive securitization of migration and integration policies in major immigration countries has been reinforced. The term securitization refers to the perception of an existent threat to the ability of a nation to maintain and reproduce itself. Securitization has emerged in a new academic literature in the field of international relations \& international politics, which even before $9 / 11$, had begun to highlight more fundamental concerns about "new" security issues, such as international terrorism, ethno-national strife and unauthorized migration. The political uses of $9 / 11$ have exacerbated the already existing discursive linkages of threat, migration and the clashes of cultures with a resulting increase in the internal and external control of migrants (Faist 2005). What has been less critically examined is the role of state securitization on DKNs. Issues of state security complicate the notions of human capital, and professional diaspora networks that were created prior to 9-11 may now be deemed

\footnotetext{
${ }^{5}$ This may also result in the formation of new trans regional coalitions such as the Maghrebi diaspora in France made up of Algerians, Moroccans and Tunisians; and in the example of 1970s Britain where the exclusionary term "black" was appropriated between immigrant South Asians, Afro Carribeans and Africans to create anti-racist alliance.
} 
as dangerous or illegal if they provide financial/technical remittances to nations that are considered threats to national security. 


\section{Conclusion}

Diaspora Knowledge Networks are a complex and multifaceted concept and their role in "homeland development" remains unclear. This paper posits two things: that globalization and capitalist economies have resulted in a change in the notion of the traditional world system, and that transnationalism and diaspora networks play an important role in creating global and regional links that give nations agency to move upwards within the new world order. It must be noted however that the current work on DKNs has predominantly been undertaken by policymakers, think-tanks, United Nations organizations and Governments bodies, and as such holds a very positivist view on the role of diaspora and their potential for development. The majority of this literature fails to recognize that as DKNs are socially constructed entities, and as such they are full of social cleavages such as gender, power and race imbalances. Therefore, making generalizations about the effectiveness of DKNs as sources of agency for nations, and agents of change in development, must be held off until further research and discussion has been undertaken on the way these social power, gender and race relations shape the needs and agendas of DKNs. In addition, there are some large gaps in the literature on DKNs, specifically in the areas of gender and development, racialization of diasporic networks and state securitization and its impacts in migrant networks. These gaps currently exist because DKNs as a concept are very new, and scholars and researchers are just starting to consider them within the study of International Relations, and much work still needs to be done. 


\section{References}

Appadurai, A. (1999). Disjuncture and difference in the global cultural economy. In S. During (Ed.), The cultural studies reader (2nd ed., pp. 220-230). New York: Routeledge.

Asis, M.M.B. (2006). “The Philippines' culture of migration", Migration Information Source, Washington, http://www.migrationinformation.org/ profiles.

The World Bank. (2003). International Migration, Remittances and the Brain Drain: A study of 24 Labor Exporting Countries. Washington DC: Adam, Richard H.

Banerjee, B. (1983). Social networks in the migration process: empirical evidence on chain migration in India. Journal of Developing Areas, 17(2): 185-196.

Bailey, A. (2010). Population geographies, gender and the Migration-Development Nexus. Progress in Human Geography, 34(3), 375-386.

Bhabha, H. K. (1999). The postcolonial and the postmodern: The question of agency. In S. During (Ed.), The cultural studies reader (2nd ed., pp. 189-208). New York: Routeledge.

Biao, X. (2005). Promoting Knowledge Exchange through Diaspora Networks (The Case of the People's Republic of China). Oxford: ESRC Centre on Migration, Policy and Society.

Brown, M. (2002). Intellectual Diaspora Networks: Their viability as a response to highly skilled emigration. Autrepart, 22, 167-178

Castells, M (2010). The Rise of the Network Society. Blackwell Publishing.

Choldin, H. (1973). Kinship networks in the migration process. International Migration Review, $7(2): 163-175$.

Clifford, J. (1997) Routes, Travel and Translation in the late $20^{\text {th }}$ Century.

Crush J. \& Frayne, B. (2007). The Migration and Development nexus in Southern Africa 
Introduction. Development Southern Africa, 24(1).

Cresswell, J. (2009). Research Design: Qualitative, Quantitative and Mixed Methods Approaches. California: Sage Publications.

Dannecker, P. (2009), Migrant visions of development: a gendered approach. Population, Space and Place, 15: 119-132

Faist, T. (2005). The Migration-Security Nexus: International Migration and Security before and after 9/11. Working Paper, No. 9. University of Bielefeld. Centre on Migration, Citizenship and Development (COMCAD)

Glick Schiller, Nina, Linda Basch and Cristina Szanton Blanc (eds)(1992) Toward a Transnational Perspective on Migration. New York: New York Academy of Sciences

Guchteneire, P. and Sammi, M. (2006). Transnational Knowledge Through Diaspora Networks. International Journal of Multicultural Societies, $8(1)$.

Gunter Frank, A. (1984). The Development of Underdevelopment. In C. K. Wilbur (Ed.), The Political Economy of Development and Underdevelopment (3rd ed.). New York: Random House.

Kapoor, D (2001) 'Diasporas and Technology Transfer'. Journal of Human Development, Vol 2, No 2, pp. $265-285$

Kapur, D \& McHale, J (2005) The Global Migration of Talent: What does it Mean for Developing Countries? Centre for Global Development.

Kofman, E. (2000). The invisibility of skilled female migrants and gender relations in studies of skilled migration in Europe. International Journal of Population Geography 6: 45-59

Koser, K. and J. Salt (1997). The geography of highly skilled international migration. International Journal of Population Geography 3: 285-303 
Kuznetsov, Y. (2004). International migration of talent and home country development: Towards a virtuous cycle (Washington DC, World Bank).

Kuznetsov, Y. (2006). Diaspora networks and the international migration of skills: how countries can draw on their talent abroad (Washington DC, World Bank).

Lin, N. (1999). Building a Network Theory of Social Capital. Conenctions, 22(1), 28-51

Mahroum, S., Eldridge E. and Daar A. (2006). Transnational Diaspora Options: How Developing Countries Could Benefit from their Emigrant Populations. IJMS: International Journal on Multicultural Societies. Vol.8, no.1, pp. 25-42.

Massey, Douglas, L. Goldring and J. Durand (1994) 'Continuities in transnational migration: An analysis of nineteen Mexican communities. American Journal of Sociology $99 ; 1492-1533$

McKinsey and Company (2003). Indian Without Borders. New Delhi

Martin, P. L. (2003). Highly Skilled Labor Migration: Sharing the Benefits.

Meyer, J.-B. (2001). Network Approach Versus Brain Drain: lessons from the diaspora. International Migration, 39(5), 91-110.

Meyer, J.-B. and J.-P. Wattiaux (2006). "Diaspora Knowledge Networks: Vanishing Doubts and Increasing Evidence." Special issue on Transnational Knowledge Through Diaspora Networks, International Journal on Multicultural Societies (IJMS) Vol. 8, No. 1, 2006: 424

Meyer, J.-B. (2007). Building Sustainability: The new frontier of Diaspora Knowledge Networks. Paper presented at the Transnationalism and Development(s): Towards a North-South Perspective.

Mercer, C. (2008). Development and the African Diaspora: Place and the Politics of Home. London: Zed Books. 
Mittleman, J., (1994). The dynamics of globalisation. Third World Quarterly, 15(3).

Mittleman, J.(1995). Rethinking the International Division of Labour in the context of globalization. Third World Quarterly 16(2).

Mittleman, J. (2001) The Salience of Race. International Studies Perspectives 10(1). 99-107.

Mohan, G. (2002) 'Diaspora and Development', in Robinson, J. (ed.) Displacements and Development, Oxford University Press: Oxford.

Newland, K., \& Patrick, E. (2004). Beyond Remittance: The Role of Diaspora in Poverty Reduction in their Countries of Origin. Washington, DC: Migration Policy Institute for the Department of International Development.

Ostergaard-Nielsen. (2003). International Migration and Sending Countries: Perceptions, Policies and Transnational Relations. London: Palgrave MacMillan Ltd.

Patterson, R. (2006). Transnationalism: Diaspora-Homeland Development. Social Forces, 84(4), 1892- 1905

Pessar P, 2005, "Women, Gender, and International migration across and beyond the Americans: Inequalities and Limited Empowerment." Expert Group Meeting on International Migration and Development in Latin America and the Caribbean copy available on http://www.un.org/esa/population/publications/IttMigLAC/P08_PPessar.pdf

Pessar, P. R. and Mahler, S. J. (2003), Transnational Migration: Bringing Gender In. International Migration Review, 37: 812-846

Portes, A. (1995) 'Economic sociology and the sociology of immigration: A conceptual overview,' in The Economic Sociology of Immigration, A. Portes (Ed.), New York: Russell Sage Foundation, pp. 1-41

Portes, Alejandro and John Walton, 1981. Labor, Class and the International System, New York: Academic Press 
Portes, Alejandro, Luis E. Guarnizo and Patricia Landolt (1999a)(eds) Transnational Communities. Special issue, Ethnic and Racial Studies 22(2)

Robertson, S. (2006). Brain Drain brain gain and brain circulation (editorial). Globalisation, Societies and Education, 4(1), 1-5.

Salehi, S. (2007). Building Bridges: The Role of the Indian Diaspora in Canada Literature Review. Kingston, ON: The Centre for the Study of Democracy.

Salt, J. (1997) International Movements of the Highly Skilled, Paris: OECD

Sassen, S. (1988). The mobility of labor and capital: A study in international investment and labor flow: Cambridge University Press.

Saxenian, A.L. (1999) Silicon Valley's New Immigrant Entrepreneurs, San Francisco: Public Policy Institute of California

Singhvi, L. M. e. a. (2001). Report of the High Level Committee on Indian Diaspora: Government of India.

Shah, N., and I. Menon (1999). Chain migration through the social network: experience of labour migrants in Kuwait. International Migration, 37(2): 361-382.

Skeldon, R. (2008). Of Skilled Migration, Brain Drains and Policy Responses. International Migration, 47(4), 4-29.

Smith, Michael Peter and Luis Eduardo Guarnizo (eds)(1998) Transnationalism from Below. New Brunswick, NJ: Transaction Publisher

Vertovec, S. and Cohen, R (eds) (2002). Conceiving cosmopolitanism: theory, context and practice Oxford: Oxford University Press, pp. 1-22

Vertovec, S. (2004) Trends and Impacts of Migrant Transnationalism, Working Paper No. 3, 
(Oxford, COMPAS; University of Oxford).

Vinokur, A. (2006). Brain Migration Revisisted. Globalisation, Societies and Education, 4(1), 7 24.

Wallerstein, E. (1979) The Modern World System: Capitalist Agriculture and the Origins of the European World Economy in the Sixteenth Century, Academic Press.

Wayland, S. (2006). The Politics of Transnationalis: Comparative Perspectives. In L. Satzewich V \& Wong (Ed.), Transnational Identities and Practices in Canada. Vancouver: UBS Press.

Wickramasekara, P. (2003). Policy responses to skilled migration: Retention, return and circulation. Perspectives on Labour Migration 5E. Geneva, International Migration Programme, International Labour Office

Wickramasekara, P. (2007). Scientific diasporas and development: some international perspectives, Workshop on A Swiss Network of Scientific Diasporas to enforce the role of highly skilled migrants as partners in development, 4 May (Lausanne, Swiss Federal Institute of Technology). Available at: http://cooperation.epfl.ch/webdav/site/cooperation/shared/diaspora/Presentation\%20 Wickramasekara-\%20ILO\%20perspectives\%20on\%20diaspora.pdf 
D $62-2.25-18$

57 